\title{
Corporate Deductibility Provisions and Financial Constraints of Innovative Entrepreneurs
}

\author{
Wolfgang Eggert ${ }^{1,2,3}$, Sebastian Heitzmann ${ }^{1}$ \\ ${ }^{1}$ University of Freiburg, Freiburg, Germany \\ ${ }^{2}$ Ifo Institute for Economic Research, University of Munich, Munich, Germany \\ ${ }^{3}$ Norwegian Center for Taxation (NoCeT), NHH, Bergen, Norway \\ Email: wolfgang.eggert@vwl.uni-freiburg.de, sebastian.heitzmann@vwl.uni-freiburg.de
}

How to cite this paper: Eggert, W. and Heitzmann, S. (2017) Corporate Deductibility Provisions and Financial Constraints of Innovative Entrepreneurs. Theoretical Economics Letters, 7, 1602-1606. https://doi.org/10.4236/tel.2017.76108

Received: June 27, 2017

Accepted: September 11, 2017

Published: September 14, 2017

Copyright @ 2017 by authors and ScientificResearch Publishing Inc. This work is licensed under the CreativeCommons Attribution International License (CC BY 4.0). http://creativecommons.org/licenses/by/4.0/

\section{Open Access}

\begin{abstract}
Corporate income tax systems around the world typically favor debt over equity in the tax base definition. The resulting distortions on financing and investment decisions of corporations are well documented in the existing literature. In this paper, we focus on the ACE proposal by the Mirrlees Review [1]. It is shown that an $\mathrm{ACE}$, which mitigates the unequal treatment of returns to owned and borrowed capital, fosters innovation by financing startups.
\end{abstract}

\section{Keywords}

Allowance for Corporate Equity, Corporate Income Tax Systems, Entrepreneurship, Finance, Public Policy

\section{Introduction}

The Mirrlees Review [1] proposes the allowance of corporate equity (ACE) as an alternative to the corporate income tax (CIT). The idea can be traced back to Boadway and Bruce [2] who introduce an allowance of the interest cost of total assets. Some of the strongest propositions defending the implementation of ACE are made by the Institute for Fiscal Studies Capital Taxes Group [3] who proposes that there are three advantages of ACE over CIT. First, the ACE system ensures neutrality for financing choices; second, an ACE tax system is neutral with respect to the method of depreciation; third, inflation does not affect the ACE system ${ }^{1}$.

${ }^{1}$ For a detailed discussion on ACE also see Brekke et al. [4] who use an oligopoly Salop model and a monopolistic competition model and show that ACE can positively affect welfare in industries with decreasing returns to scale whereas we focus on the role of the banking sector. 
Under CIT equity finance is not deductible from taxable profits. As a consequence, the normal return on equity is taxed, implying the standard tax treatment of corporate income tends to discourage investment financed by equity. This effect is potentially harmful in an environment where future returns on investment are risky and loan contracts suffer from problems of asymmetric information. Especially startups are likely to face higher technological and economic risk and, at the same time, have seemingly less assets as collateral. As a result, taxation causes an inefficient increase in borrowing costs and reduces investment especially of young and innovative firms [5].

We aim to show that ACE is not only non-discriminative but also supports entrepreneurs. In this way, it can be thought of as a public policy which fosters innovation. Innovation policy targeting startups enters public discussions recently through various policy initiatives in the United States and elsewhere ${ }^{2}$. All these initiatives identify the collection of funds for financing innovative projects as an obstacle for economic growth. Thus, the debate on innovation is closely connected the discussion of reforming the corporate tax system. Section 2 presents the model and results. Section 3 gives a short discussion.

\section{The Model}

We analyze the effects of an ACE on the financing costs of startups in a model where the established firm's equity exceeds the startups capital resources. Central to the analysis is the discussion of the financial consequences followed by a switch towards an ACE system ${ }^{3}$. Assume bank $i$ offers an interest rate $r_{i}$ for each unit of deposits $\varphi^{4}$. An increase in the interest rate offered by bank $i$ leads to a higher level of deposits $\varphi\left(r_{i}, r_{-i}\right)$ bank $i$ mobilizes, i.e., $\partial \varphi\left(r_{i}, r_{-i}\right) / \partial r_{i}>0$. Deposits and equity, $\left[B-\varphi\left(r_{i}, r_{-i}\right)\right]$, form the bank funds ${ }^{5}$.

Each of the symmetric banks chooses between established firms and startups when they make their capital allocation decision. Suppose that investment in the established firm yields an expected return that exceeds the expected return of an investment in the startup, but the bank earns higher profits when it allocates its assets in the startup and the startup succeeds.

Since deposits $\varphi(r)$ collected from depositors are invested into the firms the banks' pre-tax per period profits $\pi(r, k)$ are

$$
\pi_{E, S}=\theta_{E, S}\left[\left(r+m_{E, S}(b)\right) B_{E, S}-r \varphi\right]-\rho\left(B_{E, S}-\varphi\right) .
$$

\footnotetext{
${ }^{2}$ Prominent examples are the Innovate America strategy and the Lisbon Agenda in the European Union. Both initiatives have frequently been updated and strengthened.

${ }^{3}$ Practical examples of a transformation towards an ACE system can be found in Croatia (1994-2000), followed by Italy (partial ACE system from 1997-2003), Brazil (partial ACE system since 2000), Austria (partial ACE system from 2000-2004) and Belgium (ACE system since 2006) [1].

${ }^{4} \mathrm{Almost}$ all OECD countries run a deposit insurance system, thus it is safe to assume that depositors are only interested in the interest rates and ignore the risk of a bank's investment when they allocate their savings.

${ }^{5}$ Clearly, $\partial \varphi\left(r_{i}, r_{-i}\right) / \partial r_{-i}<0$. Note banks would choose not to hold any equity at all without governmental regulation, given equity is assumed to be costly. See Hellmann et al. [6] for a discussion.
} 
Here, $\theta_{E, S}$ describes the probability that the investment in the established firm or the startup, respectively, is successful. In the definition interest cost and opportunity cost on equity $\rho$ sum up to unit costs of capital. Revenue per unit of capital results from the interest plus a surcharge $m(b)$ that increases with the debt to equity ratio $b$. It is understood that profits are a positive number as a consequence of limited liability.

To determine banking profit let us first discuss the choice of the debt-to-equity ratio at the firm level in a model where investment takes only place once. From our above argumentation a startup is a newly established firm with a potentially weaker reputation or a not so established developed client-supplier structure compared to an established firm. We capture the difference between the two types of firms in our model by the degree of risk exposure and liability, i.e., the probability of success and the amount of equity, as we believe the two criteria have significant effect on the process of capital accumulation. Let the probability for an established firm to go bankrupt be smaller than the probability of the startup to fail, i.e., $\theta_{E}>\theta_{S}$. Denote by $X$ equity of the startup and by $X+E_{0}$ equity of the established firm. Debt capital of the startup initially exceeds equity ${ }^{6}$, that is $X<B_{0}+E_{0}^{N}$ where $E_{0}^{N}$ is the amount of equity the startup acquires during the first period on the market. The capital assets including equity and borrowed capital of the firms are denoted by $K_{t}$. The capital asset in the second period is the sum of the capital asset of the first period plus the investment from the first period, $I_{0}$. Therefore, the capital asset in period $t_{1}$ is $K_{1}=K_{0}+I_{0}$. Investment $I_{t}$ is financed through equity $E_{t}+E_{t}^{N}$ and new debt capital $B_{t}^{N}$. Production ends in the last period, implying $K_{2}=0$. Then, dividends after corporate income taxation are

$$
D_{t}=(1-\tau)\left(\pi_{t}-\left(r+m_{t}\left(b_{t}\right)\right) B_{t}\right)-E_{t},
$$

where $\tau$ denotes the tax rate, $\pi_{t}$ the profit in period $t$, and $r_{t}+m_{t}\left(b_{t}\right)$ reflects the interest rate plus a surcharge which is dependent on the rate of debt to equity $b_{t}$.

Profits can either be distributed as dividends or accumulated, so the amount of equity $E_{t}$ reduces dividends. With capital assets of $K_{t}$, the total amount of equity can be written as $K_{t}-B_{t}$. The startup and the established firm maximize $D_{0}+\frac{D_{1}}{1+r}$ by choosing the optimal amount of new borrowed capital $B_{0}^{N}$, which they borrow from the bank in period $t_{0}$.

Debt in period $t_{1}$ consists of the debt already existing in period $t_{0}, B_{0}$, and borrowing in period $t_{1}, B_{0}^{N}$. Clearly, $B_{1}=B_{0}+B_{0}^{N}$ and also $E_{1}=X+E_{0}+E_{0}^{N}$. Therefore, the ratio of debt and equity in period $t_{1}$ is $b_{1}=\frac{B_{1}}{E_{1}}=\frac{B_{0}+B_{0}^{N}}{X+E_{0}+E_{0}^{N}}$.

The firms maximization problem leads to new borrowing of $B_{0}^{N *}$. It is noteworthy to distinguish between the startup and the already established firm at his point, as the startup was not able to accumulate equity before period $t_{0}$, i.e., ${ }^{6}$ See Keuschnigg and Ribi [7] for a discussion on credit constraints of young innovative firms. 
$E_{S, 0}=0$. Therefore, given the choice of $B_{0}^{N *}$, the startup has a higher debt to equity ratio than the established firm, that is $b_{S, t}>b_{E, t}$ for $t=0,1$. We also know that $m_{S, t}\left(b_{S, t}\right)>m_{E, t}\left(b_{S, t}\right)$ which means that the startup pays a higher surplus to the established firm than the established firm does. This affects the banks asset allocation, i.e., the choice of the investment alternative.

Let the bank allocate its assets into the investments which yields the highest profits. From this, we develop a critical threshold value in the probability space such that the bank will invest in the established firm as long as it can earn higher profits than investing in the startup which is true for

$$
\frac{\theta_{E}}{\theta_{S}} \geq \frac{m_{S}\left(b_{S}^{C T S}\right) B_{S}^{C T S}}{m_{E}\left(b_{E}^{C T S}\right) B_{E}^{C T S}}:=T^{C T S} .
$$

Under ACE the startup and the established firm are able to deduct a notional interest rate on equity. Therefore new borrowing is $B_{0}^{N}=-B_{0}$, implying that the established firm will clear debts in the second period. This implies that the established firm does not need to pay a surcharge in the second period, i.e., $m_{E, 1}\left(b_{E, 1}\right)=0$. Hence, the average surcharge of the established firm $m_{E}\left(b_{E}\right)$ decreases under ACE.

In contrast, the startup is not able to pay back the full amount of its debt such that the average risk surcharge of the startup decreases to a lower degree, implying $\left|\Delta m_{E}\left(b_{E}\right)\right|>\left|\Delta m_{S}\left(b_{S}\right)\right|$.

To obtain our result it is then straightforward to compare the threshold value under ACE

$$
\frac{\theta_{E}}{\theta_{S}} \geq \frac{m_{S}\left(b_{S}^{A C E}\right) B_{S}^{A C E}}{m_{E}\left(b_{E}^{A C E}\right) B_{E}^{A C E}}:=T^{A C E}
$$

and Equation (3) shows that the introduction of an ACE tax system increases the critical value and thus gives incentives to the bank to choose the investment in the startup.

\section{Conclusion}

We discussed a promising proposition for an improvement of the corporate income tax system through public policy which we also believe will improve the possibilities for financing entrepreneurship. As we defined above, the existing system treats returns to equity and debt differently, which is often appointed as discrimination against equity finance. In our model, the current system of corporate taxation serves as a benchmark. We derive the effects of an introduction of the ACE in a model where profit maximizing banks compete for depositors and banks use the deposits to finance investment on the firms' level. Established firms and startups choose investment to maximize profits. Our key finding states that the introduction of an ACE provides incentives for the bank to invest in startups. Thus, ACE is an example not only for a solution of the problem of discrimination against equity finance, but also as a public policy product which 
supports entrepreneurship.

\section{References}

[1] Mirrlees, J., Adam, S., Besley, T., Blundell, R., Bond, S., Chote, R., Gammie, M., Johnson, P., Myles, G. and Poterba, J. (2011) The Mirrlees Review: Conclusions and Recommendations for Reform. Fiscal Studies, 32, 331-359. https://doi.org/10.1111/j.1475-5890.2011.00140.x

[2] Boadway, R. and Bruce, N. (1984) A General Proposition on the Design of a Neutral Business Tax. Journal of Public Economics, 24, 231-239. https://doi.org/10.1016/0047-2727(84)90026-4

[3] Gammie, M. (1991) Equity for Companies: A Corporation Tax for the 1990s, Report (C026). Institute for Fiscal Studies, London.

[4] Brekke, K.R., Garcia P., Armando, J., Schindler, D. and Schjelderup, G. (2017) Capital Taxation and Imperfect Competition: ACE vs. CBIT. Journal of Public Economics, 147, 1-15. https://doi.org/10.1016/j.jpubeco.2016.12.010

[5] Feldstein, M. (2012) The Mirrlees Review. Journal of Economic Literature, 50.

[6] Hellmann, T.F., Murdock, K.C. and Stiglitz, J.E. (2000) Liberalization, Moral Hazard in Banking, and Prudential Regulation: Are Capital Requirements Enough? The American Economic Review, 90, 147-165. https://doi.org/10.1257/aer.90.1.147

[7] Keuschnigg, C. and Ribi, E. (2006) Profit Taxation, Innovation and the Financing of Heterogenous Firms. CEPR DP, 7626.

\section{Submit or recommend next manuscript to SCIRP and we will provide best} service for you:

Accepting pre-submission inquiries through Email, Facebook, LinkedIn, Twitter, etc. A wide selection of journals (inclusive of 9 subjects, more than 200 journals)

Providing 24-hour high-quality service

User-friendly online submission system

Fair and swift peer-review system

Efficient typesetting and proofreading procedure

Display of the result of downloads and visits, as well as the number of cited articles

Maximum dissemination of your research work

Submit your manuscript at: http://papersubmission.scirp.org/

Or contact tel@scirp.org 